Autoria

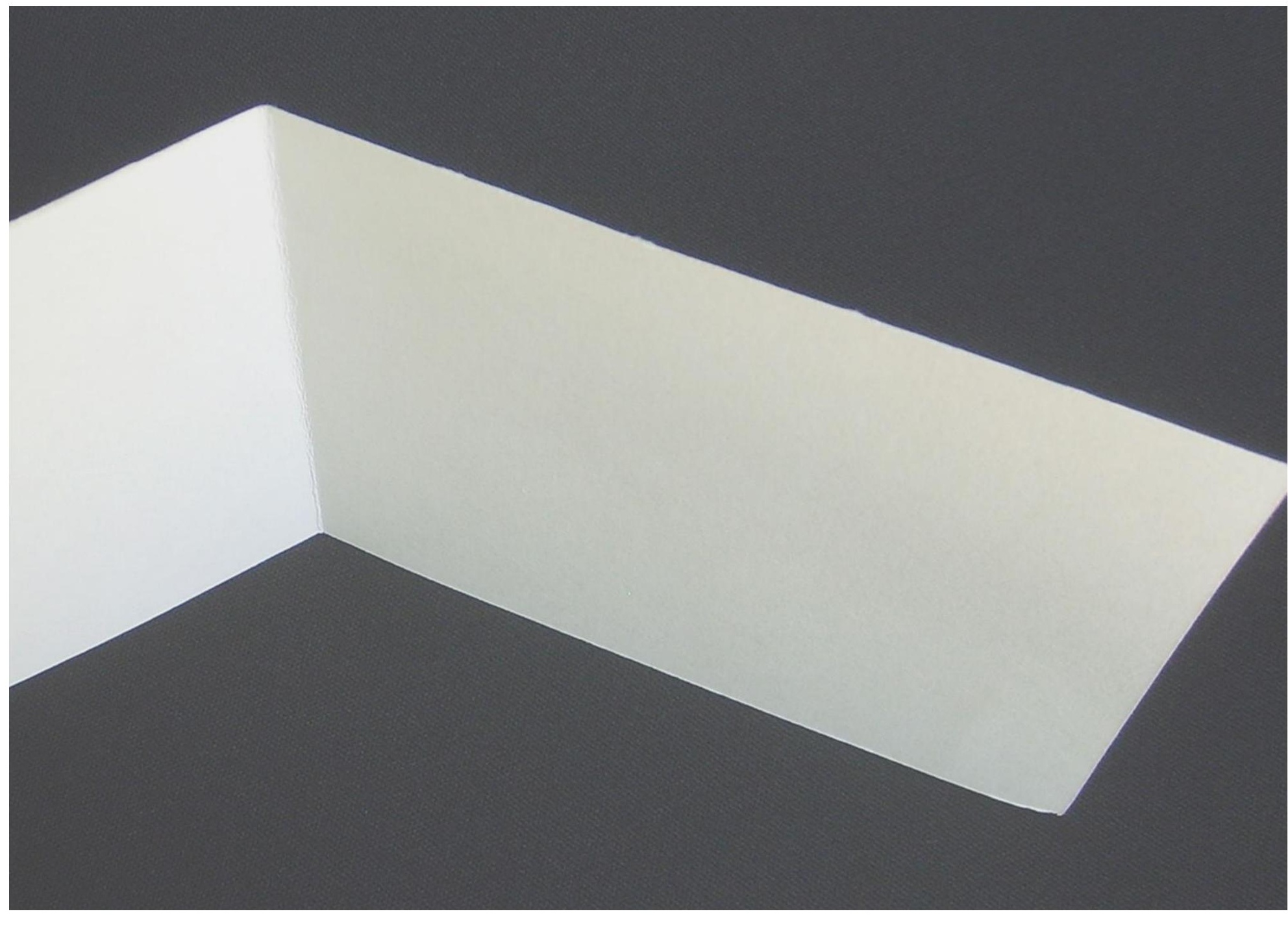




\section{Sem Título}

VIVIANE VALLADES

Viviane Vallades é doutoranda em Artes Visuais na ECA USP, com orientação do Prof. Dr. Hugo Fernando Salinas Fortes Júnior, mestra pela mesma instituição e bacharel em Artes plásticas pela UNESP. Participa de exposições e festivais, dos quais se destacam: FILE- Festival Internacional de Linguagem Eletrônica em SP em 2014 e 2012, II Salão Xumucuís de Arte Digital, Belém-Pará/ Brasil no ano de 2013, XI Bienal do Recôncavo (BA) no ano de 2012, dentre outros.

ouvirouver. Uberlândia v. 11 n. 1 p. 272-277 jan.|jun. 2015 


\section{- RESUMO}

Durante uma ação performática realizada para a câmera de vídeo, sigo um espelho em movimento e aponto uma arma para o meu reflexo, criando assim uma perseguição à minha imagem.

Os trabalhos que atualmente estou desenvolvendo fazem parte da pesquisa sobre imagens em movimento e artes visuais, com ênfase nos suportes (de projeção de imagens e suporte corpo).

Os suportes/superfícies de projeção de imagens em minhas instalações frequentemente tornam-se elementos expressivos; são materiais escolhidos por suas qualidades plásticas, temporais e metafóricas. Já o meu corpo, que está frequentemente presente tanto nos trabalhos que utilizam a projeção sobre diversas superfícies como nos que não as utilizam, encontra-se inserido na fisicalidade das imagens. Por meio de ações e composições que realiza, procura trazer reflexões, problemáticas sobre nossa existência.

\section{- PALAVRAS-ChAVE}

Performance, imagens em movimento, corpo.

\section{- ABSTRACT}

During a performance action performed for the video camera, follow a moving mirror and point a gun at my reflection, thus creating a chase in my image.

The work that I am currently developing part of research on motion pictures and visual arts, with an emphasis on supports (of image projection and support body).

Supporters / image projection surfaces in my installations often become expressive elements; materials are chosen for their artistic qualities, temporal and metaphorical. Already my body, which is often present in both works using the projection on various surfaces like us that do not use, is inserted into the physicality of the images. Through actions and performs compositions, seeks to bring reflections, issues about our existence

\section{- KEY WORDS}

Performance, moving images, body. 


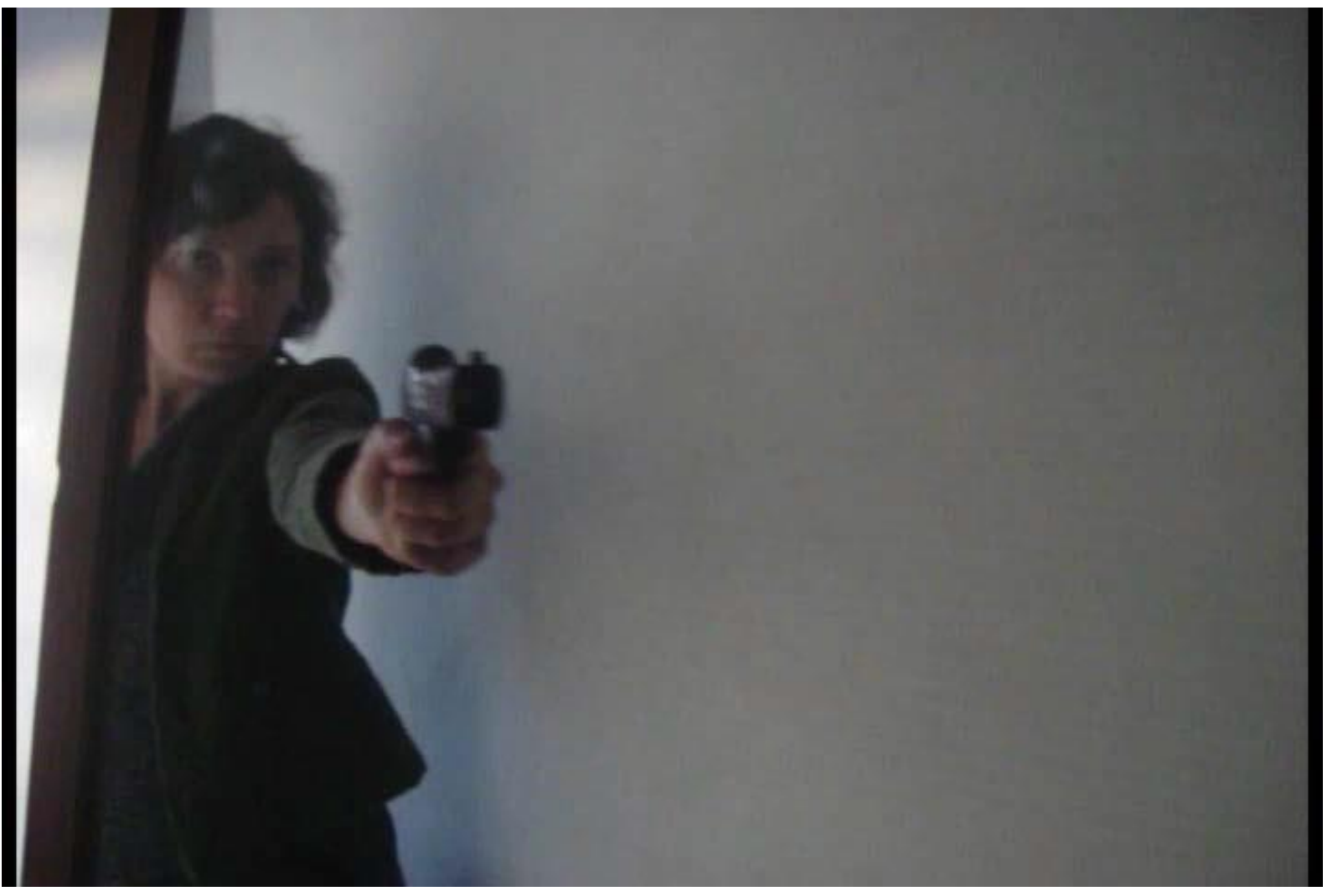

https://www.youtube.com/watch?v=LtPi-MVhG50\&feature=youtu.be

ouvirouver. Uberlândia v. 11 n. 1 p. 272-277 jan.|jun. 2015 


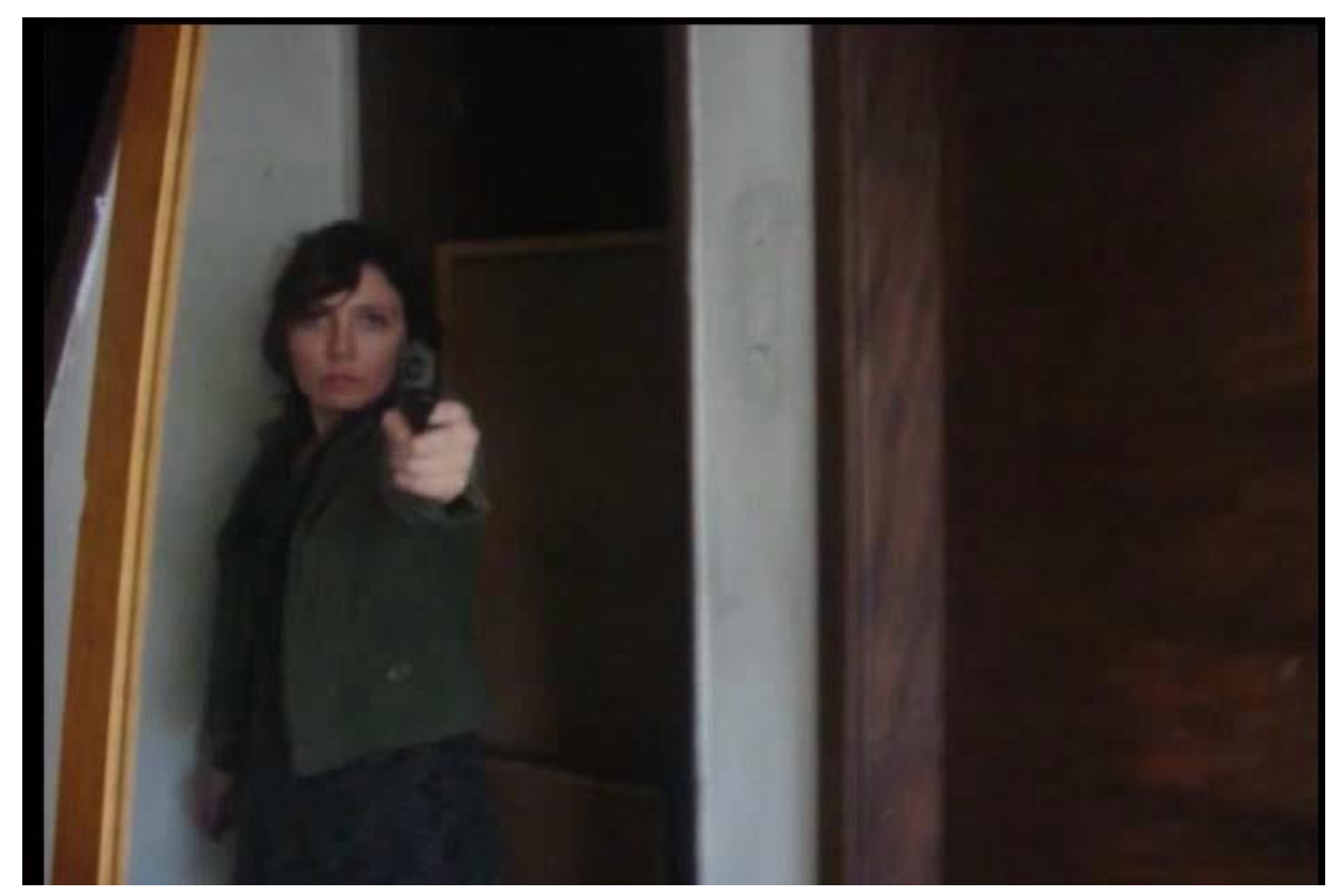

275 口

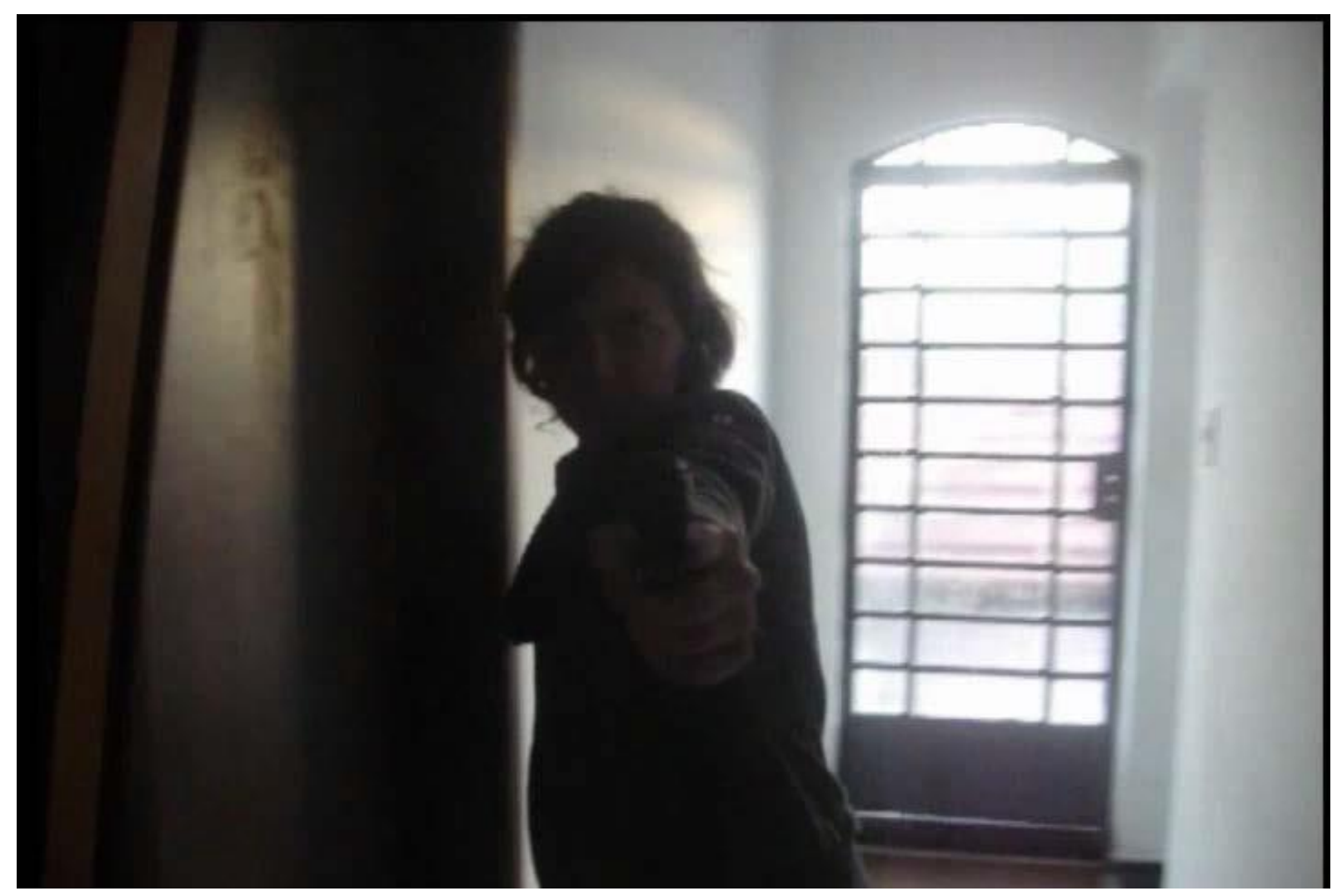

ouvirouver . Uberlândia v. 11 n. 1 p. 272-277 jan.|jun. 2015 
- 276

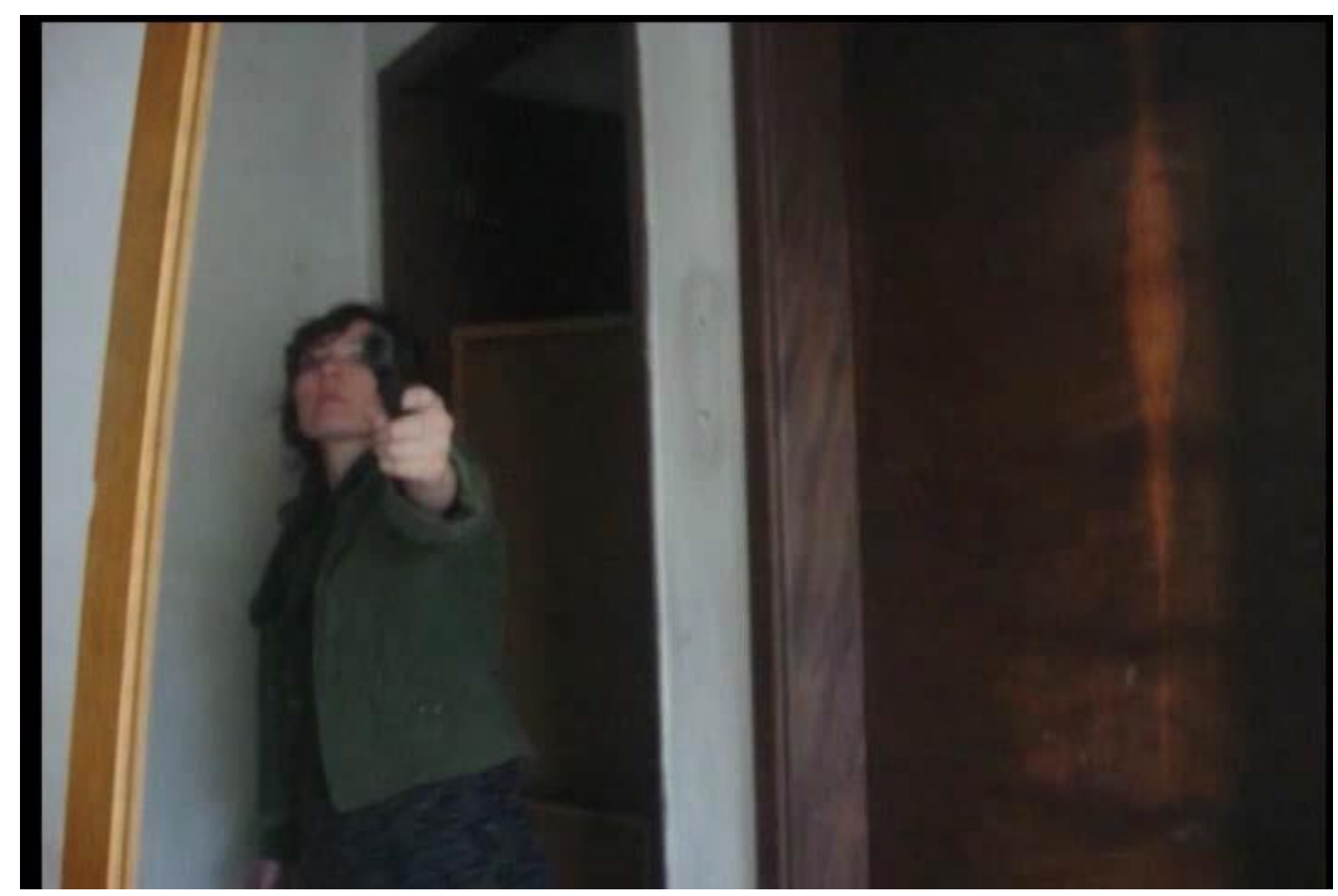

ouvirouver . Uberlândia v. 11 n. 1 p. 272-277 jan.|jun. 2015 

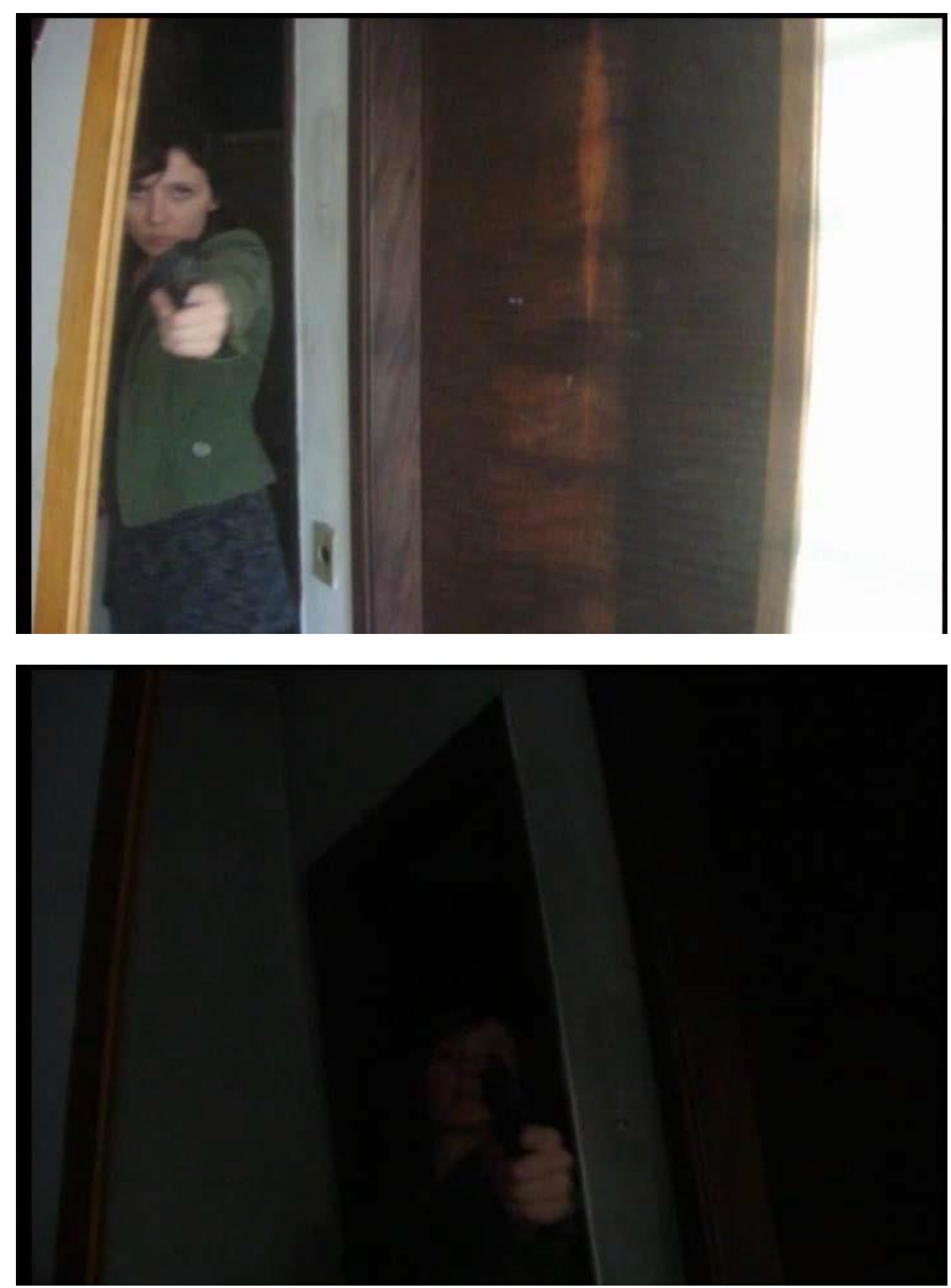

Viviane Vallades. Frames do vídeo "Sem Título" com duração de 04’25”, 2015, SP, Brasil. Fonte da autora. 